\title{
Macrofossils from a Late-Glacial Deposit at Cambridge, Massachusetts
}

\author{
GEORGE W. ARGUS and MARGARET B. DAVIS
}

W. P. Fraser Herbarium, University of Saskatchewan, Saskatoon, and De. partment of Botany, University of Michigan, Ann Arbor

\begin{abstract}
Macrofossils were isolated from late-glacial sediments exposed in open section in a building excavation at Gambridge, Massachusetts. The lower portion of the profile contained leaves of three species of herbaceous plant species now generally found in arctic or alpine regions, and fragments of a water beetle belonging to a species that now occurs characteristically in regions of boreal forest. The upper portion of the profile contained spruce needles, spruce wood and a spruce cone, and seeds and leaf fragments representing four species of water plants. Correlation by means of pollen analysis indicates that the sediments may have been deposited between about 10,000 and 13,000 years ago. The occurrence of arctic-alpine species in the lower portion of the profile indicates that areas suitable for the survival of these species existed both beyond the margin of the Wisconsin ice sheet at the time of its maximum advance, and in Massachusetts at a time of glacial retreat.
\end{abstract}

\section{INTRODUCTION}

An understanding of vegetational history depends largely on the study of fossil deposits. Although interest in fossil pollen deposits in New England has greatly increased within the last decades, little attention has been given to macrofossils. They are, however, in some ways far more valuable than pollen as indicators of past vegetation. A major advantage is the increased possibility for specific, rather than generic, identifications. Macrofossils also provide almost conclusive evidence that the plants represented were living in the vicinity of the site at the time of deposition; unlike pollen, large and delicate plant parts are not usually transported for long distances, nor are they rebedded from older deposits without morphological change. On the other hand, because their preservation is more sensitive to conditions of sedimentation, macrofossils are relatively rare, and are difficult to use for quantitative estimates of past vegetation.

Recent investigations in the Midwest (Wilson, 1932, 1936; Rosendahl, 1948; Goldthwait, 1958; Burns, 1958) and in Nova Scotia (Schofield and Robinson, 1960) have demonstrated the usefulness of Quaternary macrofossils, particularly when studied in conjunction with radiocarbon dating and pollen analysis. In New England, however, few macrofossil deposits are known. Many years ago leaves of arctic-alpine and boreal plant species were reported from varved clays in the Connecticut valley in Massachusetts (Emerson, 1898). The find is of particular interest because it demonstrates the existence of vegetation at a time when "glacial" clay was still being deposited. Emerson also found both plant and animal remains in what appear 
to have been postglacial lake and river deposits nearby. Farther north, near Colbrook, New Hampshire, unvarved clays exposed in section in the Connecticut River valley were found to contain leaves of arcticalpine and boreal species including herbs and trees (Hollick, 1931). Leaves of three shrub and one tree species have also been reported from marine clays near Waterville, Maine (Berry, 1917). More recent macrofossil finds in New England have been dated by the radiocarbon method. A Populus log found in lake mud near Athol, Massachusetts, has been dated at 10,700 \pm 800 (M-413) and 10,800 \pm 250 (W-361) years before the present (Davis, 1958), and a Picea $\log$ from gravels near Hartford, Connecticut, at 10,650 \pm 320 years B.P. (Y-251) (Flint, 1956). One of the more interesting macrofossil finds in New England is the horn core of a bison, found in stratified sands and gravels near Harvard, Massachusetts. The specimen was identified as Bison crassicornis Richardson, an extinct species known previously only from late Pleistocene deposits of northern Europe eastward to Siberia, and Alaska (Romer, 1951). The radiocarbon age determination for the specimen is given as 21,200 \pm 1000 years B. P. (Rubin and Alexander, 1960).

The present paper describes macrofossils from late-glacial sediments exposed in open section in a building excavation at Cambridge, Massachusetts. The sediments appear to have been deposited in a small pond that formed as buried ice melted in the underlying sand and gravel (Lexington glacial outwash, Judson, 1949). Comparison of the pollen profile from the sediments (Davis, 1960) with profiles from sites where radiocarbon dates are available (Deevey, 1958) indicates that the sediments may have been deposited between 10,400 and 12,800 years ago. They are thus similar in age to the Two Creeks forest bed in Wisconsin (Wilson, 1932, 1936) and to the late-glacial Dryas floras of northwestern Europe (Iversen, 1953).

Acknowledgments.-We are indebted to Mrs. Sabra B. Black and Mrs. Marian R. Robertson for identifying, respectively, the Picea cone and Polytrichum fragments, and for providing encouragement and stimulating discussion. We also wish to express our appreciation to Mr. W. J. Brown, Entomology Research Institute, Canada Department of Agriculture, who identified the specimen of Deronectes griseostriatus and supplied information concerning the present distribution of the species. It is a pleasure to thank Mr. John P. Schafer, United States Geological Survey, who called our attention to the occurrence of the late-glacial deposit and made available information concerning the stratigraphy of the site. This work was done at the Biological Laboratories and University Herbarium, Harvard University.

\section{Description of Site}

Late-glacial sediments containing macrofossils were exposed in open section by an excavation made in the spring of 1958 for the Cambridge Electron Accelerator, Cambridge, Massachusetts. The excavation was located between the Harvard Biological Laboratories, on Divinity Avenue, and Hammond Street. The late-glacial sediments 
were exposed on the north wall of a trench running more or less parallel to Hammond Street. The deposit was lens-shaped, about $2 \mathrm{~m}$ maximum thickness, and about $10 \mathrm{~m}$ horizontal extension. Large blocks of sediment were taken from the site to the laboratory, where fossils were isolated from them. The approximate position of the samples in relation to samples collected for pollen analysis was recorded at the time they were collected; stratigraphic positions of fossils will be referred to in this paper in relation to the pollen sequence. The latter was divided into three pollen zones: the Herb pollen zone $(T)(0-48 \mathrm{~cm}$ above gravel where the pollen samples (series I) were collected); the Lower Durham Spruce pollen zone (A-1-2-3) (49-132 cm levels); and the Upper Durham Spruce pollen zone (A-4) (133-151 cm levels) (Davis, 1960). A thin layer of dark brown, humified peat which overlay these deposits was not studied in detail.

\section{Fossils from the Herb Pollen Zone (Zóne T)}

The sediments of this zone consisted of sandy silt with irregular black laminae and lenses of coarse sand, and sandy gray-green organic mud. Leaves were abundant in the sediments, except in the thicker sand lenses, and could be found in groups along bedding planes or as isolated fossils that did not appear oriented in relation to bedding planes. The leaves were dark brown in color, and although they appeared well-preserved, were without tensile strength and crumbled when dry. Very few of the leaves could be removed intact from the sediments. Because it was often difficult to clear the sand and silt away from larger specimens without tearing them, the leaves that were isolated and identified may be smaller than the average in the sediments. The sediments contained rootlets that apparently penetrated the sediments subsequent to their deposition. The rootlets were not identified, but may represent aquatic plants that grew in the pond at the time the sediments of pollen zone A-1-2-3 were deposited.

Macrofossils from the lower and upper parts of the zone were collected separately, but no differences in the flora could be discerned. Therefore the fossils in the entire pollen zone are considered as a single group. Representative specimens of the species discussed here are preserved in the paleobotanical collections of the Botanical $\mathrm{Mu}$ seum, Harvard University.

Salix herbacea L.- Leaves identified as this species were the most abundant type in theposit (Figs. 1, 2, 3). Those leaves that were isolated varied in length from $4-6 \mathrm{~mm}$. This is somewhat small for the species but leaves of this size can be found on almost all individuals and the isolating technique, described above, selected for small leaves.

The leaves of $S$. herbacea may sometimes be confused with those of Betula glandulosa Michx. However, two lines of evidence were used to support our identifications. The first is the direct evidence provided by the distinctive venation of $S$. herbacea leaves in which the first 2-3 "pairs" of lateral veins originate at or near the base of 
the leaf blade (Figs. 1 and 3 ) and are not evenly spaced along the midrib as in Betula glandulosa. The second is the indirect evidence provided by the presence of Salix capsules (Fig. 9) which compare favorably with those of $S$. herbacea both in size of capsule and length of pedicel. No fruits or seeds of Betula were recovered. Palynological evidence suggests further that Salix was more abundant than Betula in this area. Iversen (1947) found in surface samples from lakes in Greenland that Salix is less well represented in pollen spectra than Betula nana. Assuming that the Salix and Betula species present at Cambridge produced pollen in quantities similar to Greenland species, the differences in pollen frequency for these genera in Zone $\mathrm{T}$ (Salix 3-10 per cent and Betula 2. per cent) suggest that Salix was a more abundant member of the flora than Betula.

The small round bodies on the leaf in Figure 3 are fungal structures, probably pycnidia, of an unidentified species. Many of the leaves were similarly infected. A rootlet which apparently penetrated the leaf after deposition can be seen in Figure 2.

Salix herbacea is an amphi-atlantic species (Hultén, 1958) found in northern Europe, Iceland, Greenland, Newfoundland, northern Quebec, eastern Northwest Territories, and the southern portion of the Canadian Arctic Archipelago: An earlier more widespread range to the south is suggested by disjunct occurrences in the Shickshock Mountains of the Gaspé Peninsula, especially on the granitic slopes of Mt. Jacques Cartier (Tabletop Mountains) and the hornblende schist of Mt. Albert, the White Mountains of New Hampshire, notably Mt. Washington where it is of restricted occurrence, Mt. Katahdin in Maine, and Mt. McIntyre in the Adirondack Mountains of New York. As a fossil it is reported frequently in deposits associated with the British glacial periods (Godwin, 1956).

The species is arctic-alpine in its distribution. In its southern area it generally occurs on moist, well-drained, lee slopes which in many cases are influenced by the presence of late-snow patches. In such sites it may be locally very abundant, trailing among mosses and other low ground cover. Polunin (1940) notes that although it is particularly characteristic of late-snow patches, " . . . in the south [i.e., northern Quebec] it occurs in a wide range of habitats, including dry sandy areas, herb slopes and grassy meadows, and sometimes even marshes."

Dryas integrifolia Vahl.-Leaves representing this species were also abundant in the sediments. The leaves had prominently cordate bases and inrolled edges (Figs. 4, 5, 6). One specimen showed the characteristic tomentum on the lower leaf epidermis (Fig. 5). The size of these leaves $(3-5 \mathrm{~mm}$ ) is somewhat small for the species, but this may be the result of our isolating technique. Leaves of Vaccinium oxycoccus L. superficially resemble those of Dryas integrifolia but lack the tomentose-lower leaf surface found on one of our specimens. Both Ericaceous and Dryas-type pollen were present in the sediments.

Dryas integrifolia is ubiquitous in northern North America both in regard to geographic distribution and habitat (Porsild, 1957). It 
ranges all across Alaska, Canada and Greenland, being reported from the northernmost botanical locality (Lockwood Island) in northern Greenland (Polunin, 1940), south, in eastern America, to Anticosti Island and the Shickshock Mountains where it is found in calcareous habitats. Although the species occurs most commonly in dry, exposed, and poorly vegetated localities, it shows a wide range of tolerance to environmental conditions. Polunin (1948) lists it with Salix herbacea and Vaccinium uliginosum var. alpinum as commonly associated components of late-snow areas, mixed heaths, luxuriant lowland heaths, and dry valley sides in northern Quebec and the southern part of the Canadian Arctic Archipelago. Generally regarded as a calciphile, it
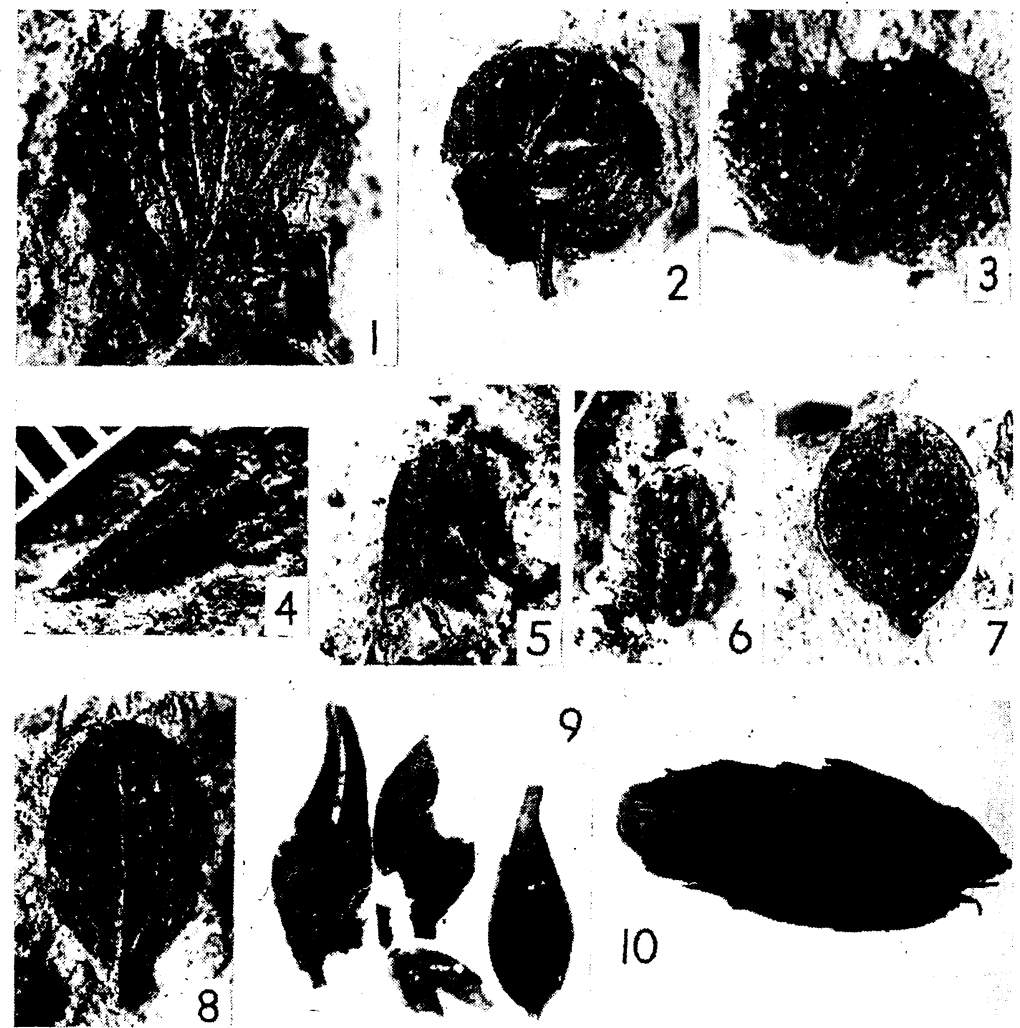

9

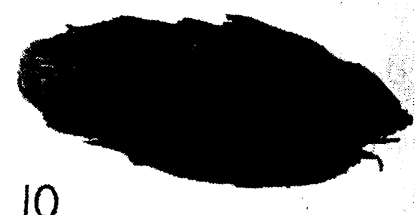

Figs. 1-10.-Macrofossils from Cambridge, Massachusetts. 1. Salix herbacea L., leaf, 4x. 2. Salix herbacea L., leaf, 4x. 3. Salix herbacea L., leaf with fungal structures, $5 x$. 4. Dryas integrifolia Vahl., leaf with inrolled edges, $4 x$. 5. Dryas integrifolia Vahl., under surface of leaf, tomentum just visible in photograph, 5x. 6. Dryas integrifolia Vahl., upper surface of leaf with cordate base, 4x. 7. Vaccinium uliginosum L. (var. alpinum Bigel. ?), leaf, 4x. 8. Vaccinium uliginosum L. (var. alpinum Bigel, ?), leaf, 5x. 9. Salix capsules, 5x. 10. Picea cone, $2 \mathrm{x}$. 
is absent from the granitic mountains of New England and New York which now support Salix herbacea and Vaccinium uliginosum var. alpinum.

Vaccinium ulginosum L. (var. alpinum Bigel. ?).-Leaves of this species were recovered from the lower portion of the Herb pollen zone (Zone T) (Figs. 7 and 8 ). The leaves compared very favorably in size, shape, and venation with material from eastern North America, and it is very likely that the "microphyllous" variety of the species is the one represented in our deposit. This generally abundant species appears to exhibit, in the southern part of its range, a wide tolerance to environmental conditions (Polunin, 1940). It is an important element in heaths, marshes, and open gravelly areas where it occurs most commonly on acid soils (Polunin, 1948).

The range of this American, arctic-alpine species is very similar to that of Salix herbacea and Dryas integrifolia. It extends southward in eastern United States, as does $S$. herbacea, into the alpine zones of the granitic peaks of the White Mountains and the Adirondack Mountains. In this region it is very much more common than $S$. herbacea and may cover extensive areas.

Betula glandulosa Michx. ?-This species has not been positively identified from our material but several of the leaves tentatively assigned to Salix herbacea (not those illustrated) may belong to Betula. It is listed here as of probable occurrence.

Two or three other leaf types were found that could not be identified with certainty. Also observed in the sediments were unidentified seeds, and two Carex achenes.

Polytrichum juniperinum Hedw. and P. piliferum Hedw. were identified from fragments by Mrs. Marian Ropes Robertson on the basis of leaf shape and size and shape of plant. Both species are wide-ranging in North America and occur today in Massachusetts. $P$. piliferum is characteristically found in open situations as, for example, granite ledges, while $P$. juniperinum occurs commonly in moist and shaded habitats.

Deronectes griseostriatus (DeG.).-Fragmentary remains of this species were identified by Mr. W. J. Brown. The fragments consisted of the crushed basal portion of one wing cover, a prosternum, metasternum, hind coxae and hind trochanters. Deronectes griseostriatus (DeG.) is a holarctic water beetle, family Dytiscidae. In this continent, it ranges south of the tree limit from Labrador to Alaska and south to New Jersey, Michigan, Iowa, Arizona and southern California. It is most common in the boreal forest, but occurs south of it in regions of deciduous forest. Although not usually found in tundra regions, the species has been collected four miles beyond the northern limit of trees at Churchill, Manitoba, and on barren, treeless islands off the southern coast of Labrador (Mr. W. J. Brown, personal communication). 


\section{Fossils from the Durham Spruge Pollen Zones}

The Lower Durham Spruce pollen zone (A-1-2-3) was represented in the section by gray-green and red-brown sandy organic mud with rootlets, and the Upper Durham Spruce pollen zone (A-4) was represented by red-brown organic mud. The red-brown color of the muds of Zone A-4 and the upper portion of Zone A-1-2-3 appeared to be secondary staining by humic material leached from the overlying layer' of humified peat.

The leaf fossil flora described from the Herb pollen zone occurred in the lowermost $2-5 \mathrm{~cm}$ of the $84 \mathrm{~cm}$ thickness of Zone A-1-2-3. Above this level the following fossils were found.

Picea.-Two spruce needles were found in the sediments. One occurred in sediments equivalent to the lower portion of Zone-A=1-2-3. Another spruce needle, and a fragment of wood that was sectioned and identified as Picea sp. occurred in the section in sediments equivalent to upper Zone A-1-2-3 or to Zone A-4. A cone (Fig. 10), identified by Mrs. Sabra Bowman Black, closely resembles cones of Picea mariana (Mill.) BSP. The species identification is tentative, however, as the tips of the cone scales, the morphology of which is usually used to distinguish cones of $P$. mariana and $P$. rubens Sarg., had been broken from the specimen. In length, $22 \mathrm{~mm}$, it most closely resembles $P$. mariana, but the cone is immature and may not have attained full growth before fossilization.

Pollen from the mud immediately surrounding the spruce cone was analyzed to define its stratigraphic position in relation to the pollen sequence. The pollen spectrum, which included $30 \%$ Picea, 8\% Pinus, $7 \%$ Betula, 2\% Quercus, 2\% Ostrya-Carpinus, $0.5 \%$ Fraxinus, $11 \%$ Myricaceae, 2\% Salix, 5\% Gramineae, 20\% Cyperaceae, 5\% Tubulifloreae, 3\% Artemisia and 1\% Caryophyllaceae pollen (total pollen, 213), resembles pollen spectra found in samples between the 70 and $100 \mathrm{~cm}$ levels where the pollen samples were collected. These levels include the lower portion of Zone A-1-2-3 exclusive of the lowermost levels, where birch pollen percentages are maximal.

Species of Picea now range throughout the boreal forest, as scattered populations well into the arctic tundra, and at high elevations and in bogs far to the south.

Najas flexilis (Willd.) Rostk. \& Schmidt.-This identification was based on numerous seeds found throughout the A-1-2-3 zone. The seeds are slender, varying in size from 2.3-2.8 mm long, dark brown and highly lustrous. They have a reticulate appearance produced by the rows of very small but prominent cells. This species ranges today from Newfoundland across southern Quebec west to Minnesota, and south to Iowa, Ohio and Virginia. The species is not found in the central part of the continent, but appears again in Alberta and British Columbia to Oregon (Fernald, 1950). It is commonly found in the 
southern part of New England in the area of our deposit. The species is abundant as a fossil in the boreal period deposits of England and Scandinavia (Godwin, 1956).

Najas flexilis is found in a variety of habitats: shallow fresh water, tidal pools, and marly ponds. Its presence in our deposit may indicate shallow, still water.

In the A-1-2-3 zone several fruits and leaf fragments of Potamogeton were found. Three species were identified on the basis of this material. Preliminary identification was made using Ogden's (1953) unusual and invaluable key to North American Potamogeton.

Potamogeton robbinsii Oakes.-Several leaf fragments of this species were identified. They are linear (4-6 mm wide) and characterized by finely serrate margins. Numerous lateral veins (about 30 ) and the auricled leaf base further support the identification. Fernald (1950) reports this species as preferring muddy waters, and ranging across southern Canada from New Brunswick to British Columbia and across the United States from Delaware and Alabama to Wyoming and Oregon. It is present today in the area of our deposit.

Potamogeton pusillus L.-Fruits were identified on the basis of their size $(2.1 \times 1.6 \mathrm{~mm})$ and the presence of a marginal beak. The specimens compared well with material from southern New England. This species generally prefers basic or alkaline waters and ranges across southern Canada from the Gaspé Peninsula to British Columbia and south in the United States to Virginia, Texas and Mexico (Fernald, 1950). It is a highly variable species of circumpolar distribution in which several varieties are recognized. It occurs commonly in the area of our deposit both in ponds and slow-moving rivers.

Potamogeton lateralis Morong.- - Two fruits were identified on the basis of their size $(1.8 \times 1.4 \mathrm{~mm}$ and $1.9 \times 1.3 \mathrm{~mm})$, the presence of a short medial beak, and the two-grooved back. This species is found in isolated localities in eastern Massachusetts, Connecticut, New York, Michigan and Minnesota (Gleason, 1952). It has been collected with a variety of $P$. pusillus in the Charles River, Massachusetts.

Pollen of Potamogeton occurred in very low percentages $(<1$ percent) in samples from $70-125 \mathrm{~cm}$ levels (middle and upper portion of Zone A-1-2-3). Two Carex achenes, and several types of unidentified seeds were also found in the sediments.

\section{Discussion and Gonclusions}

The macrofossils preserved in the sediments of the Herb pollen zone (Zone $\mathrm{T}$ ) indicate that the species represented were living in the vicinity at the time of deposition 11,000 to 13,000 years ago. The approximate age is based on correlation of the pollen diagram with diagrams from radiocarbon-dated sediments at other sites in southern New England (Davis, 1960). The presence of three arctic-alpine 
species, Salix herbacea, Dryas integrifolia and Vaccinium uliginosum (var. alpinum ?) in the Cambridge area during this time provides us 1) with evidence that some species of present-day arctic-alpine affinities existed in areas beyond the ice sheet during the late Pleistocene; and 2) with information enabling us to speculate about the nature of the environment near the site of deposition.

These species, and presumably others of similar affinities ${ }^{1}$ were available for colonization of the newly deglaciated landscape in Massachusetts. This implies that at least small populations of these species survived the Wisconsin glaciation along the ice front, or in suritable situations south of the ice border, or on land exposed by lowered sea levels. Apparently these populations migrated northward and westward in the wake of the retreating ice to the Arctic where, perhaps merging with "populations that survived in other areas, the species attained their present ranges. Although arctic-alpine species have been eliminated from the flora to the south where forest species have become established, small populations of a few species have survived on suitable alpine summits. Each of the species found in our deposit is today wide-ranging in northern North America. However, no two of their ranges are identical. Dryas integrifolia and Vaccinium uliginosum var. alpinum can be regarded as American arctic-alpine species. They range from Alaska to Newfoundland and southward both in the eastern and western mountains. Salix herbacea, however, is an amphi-atlantic arctic-alpine species whose range, in North America, is definitely eastern. The differences' in the absolute size of the present ranges of these species may be related, in part, to the size and number of areas in which the species survived the last glaciation. Species like Dryas integrifolia and Vaccinium uliginosum might have survived not only in eastern America but also in the Rocky Mountain area and in the unglaciated interior of Alaska and Yukon. Salix herbacea, on the other hand, might have survived only in eastern America, its range being restricted largely by time, and its migration still continuing. This hypothesis does not imply that genetic factors or differences in efficiency of propagule dissemination are not important factors in migration; it simply suggests that factors such as location of survival areas, and time available for migration, might be sufficient to explain some present-day ranges.

If we consider the eastern portions of the ranges of these species we find a different grouping. Salix herbacea and Vaccinium uliginosum var. alpinum occupy the granitic, schistose peaks of the White Mountains, the Adirondack Mountains, Mt. Katahdin in Maine, and

1 E.g., Salix uva-ursi Pursh [reported as S. cutleri Tuck.], Oxyria dignya L., Arctostaphylos alpina (L.) Spreng., A. uva-ursi Spreng. ?, and Rhododendron lapponicum (L.) Wahl. identified by Emerson (1898) from varved clay deposits in Massachusetts; and Salix reticulata L. and Loiseleuria procumbens (L.) Desv. [reported as Chamaecistus procumbens (L.) Kuntze ?] identified by Hollick (1931) from clays near Colbrook, -New Hampshire. 
the Shickshock Mountains of the Gaspé Peninsula. The third species, Dryas integrifolia, is known in the eastern portion of its range only from the Gaspé Peninsula, where it is found on the limestone cliffs above the Lac des Americains (on Mt. Jacques Cartier), Mt. Percé, and the cold, northerly calcareous walls of cliffs near Percé. The differences in the ranges of these species in eastern America may be related to species adaptions to acidic or basic soils. The exact nature of this adaption is unclear, however, for although the species are now isolated on areas with contrasting soil $\mathrm{pH}$, they did exist together in the Cambridge area and do exist together today in many places in northern Quebec and the southern Arctic Archipelago. Further, Salix herbacea is considered to be a basiphilous species in northern Scandinavia (Godwin, 1956), and Vaccinium uliginosum var. alpinum is found on the wet serpentine plateau of Mt. Albert (Gaspé). Today in northern Quebec and the southern Arctic Archipelago these three species are found together in habitats characterized by a plentiful supply of water, mostly from snow drifts, and good drainage and aeration (Polunin, 1948). These areas are usually small in extent, but numerous, in the Arctic. Areas answering this description may. have existed in the vicinity of the Cambridge site. On the other hand; it is perhaps unnecessary to assume that these three species existed in the same habitat; a mosaic of habitats is very likely to have been present. Their occurrence at Cambridge does, however, lend some support to the idea that species which survived south of the ice front migrated northward as individual species and not as communities.

The arctic-alpine species of Zone $\mathrm{T}$ do not occur today under forest canopy and are presumably shade-intolerant, their presence indicates at least local treeless conditions. Apparently the environment - was not characterized only by the absence of shade. If so, representatives of the many highly competitive "temperate" shadè-intoleraht plant species might have been expected among the macrofossils. Their absence suggests that some other factors of the environment, now characteristic of arctic and alpine regions; prevailed in the area at this time. These factors were probably low temperatures at some critical time in the life cycle (possibly related to the length of the growing season) or soil instability or both. The instability of thin soil in areas of glacial moraine, especially where drift overlies stagnant ice, is well known and undoubtedly was an important factor of the environment in which the arctic-alpine species existed.

The occurrence in the sediments of arboreal pollen, especially Picea and Pinus, and of a water beetle (Deronectes griseostriatus) characteristic today of forested rather than tundra regions, is evidence that boreal forest species also existed somewhere near the site of deposition. It is very likely that in our area there were present both forest and "tundra" species, the latter occupying the more unstable areas with shallow soils such as outwash plains, newly exposed moraine 
and moraine overlying ice, and the former occupying the more stable sites with deeper soils. A mosaic of vegetation might have existed, therefore, in the area. Although the discovery of these arctic-alpine species cannot be used as evidence that a band of "tundra" bordered the ice front, their presence cannot be ignored or regarded as an isolated phenomenon. They do suggest that the periglacial area provided major areas of survival for these and other species, and that at the time of glacial retreat there existed, near sea level in-eastern Massachusetts, habitats of an arctic-alpine nature.

The sediments of the upper portion of the profile $:$ (pollen zones A-1-2-3 and A-4) were deposited more or less contemporaneously with the Two Creeks forest bed in Wisconsin and the advance of Valders ice (Davis, 1960). At this time trees were more abundant in the Cambridge area, as the occurrence of Picea needles, wood, and cone indicate. The introduction here of Potamogeton and Najas indicates a possible change in the environment of the pond which permitted their growth, or perhaps a late introduction of these "southern" species. Leaves of shade-intolerant herbs and low shrubs are absent from the upper part of the profile, either because conditions of sedimentation changed or because these species no longer occurred in the local vegetation. The change in the macrofossil flora and the increase in the number of arboreal pollen types represented in the sediments may be indicative of a major vegetational change.

\section{REFERENGES}

Berry, E. W. 1917. Pleistocene plants in the marine clay of Maine. Torreya, 18: $160-163$.

Burns, G. W. 1958. Wisconsin age forests in western Ohio. II. Vegetation and burial conditions. Ohio J. Sci., 58:220-230.

Davis, M. B. 1958. Three pollen diagrams from central Massachusetts. Am. J. Sci., 256:540-570.

1960. Pollen analysis of a late-glacial deposit at Cambridge, Massachusetts. Manuscript.

Deevey, E. S. 1958. Radiocarbon-dated pollen sequences in eastern North America. Veröff. Geobot. Inst. Rübel in Zürich, 34:30-37.

Emerson, B. K. 1898. Geology of old Hampshire County, Massachusetts, comprising Franklin, Hampshire, and Hampden Counties. U. S. Geological Survey Monograph, 29, 790 p.

Fernald, M. L. 1950. Gray's manual of botany, eighth edition. American Book Company, New York. 1632 p.

FLINT, R. F. 1956. New radiocarbon dates and late-Pleistocene stratigraphy. Am. J. Sci., 254:265-287.

Gleason, H. A. 1952. The new Britton and Brown illustrated flora of the northeastern United States and adjacent Canada. Vol. 1. Lancaster Press, Inc., Lancaster, Penn. 482 p.

Godwin, H. 1956. The history of the British flora. Cambridge University Press. $384 \mathrm{p}$.

Goldthwair, R. P. 1958. Wisconsin age forests in western Ohio. I. Age and glacial events. Ohio J. Sci., 58:209-219. 
Holliak, A. 1931. Plant remains from a Pleistocene lake deposit in the upper Connecticut River valley. Brittonia, $1: 35-55$.

Hultén, E. 1958. The amphi-atlantic plants and their phytogeographical connections. Kungliga Svenska Vet. Handlingar, IV, 7:3-340.

Iversen, J. 1947. Plantevaekst, Dyreliv og Klima i det senglaciale Danmark. Geol. Fören: i Stockholm Förhandl., 69:67-78. 1953. Radiocarbon dating of the Alleröd period. Science, 118:6-11:

Judson, S. 1949. The Pleistocene stratigraphy of Boston, Massachusetts, and its relation to the Boylston Street Fishweir. In The Boylston Street Fishweir II. Papers Peabody Foundation for Archaeology, 4:7-48.

Ogden, E. 1953. Key to the North American species of Potamógeton. New York State Mus. Circ., 31:3-11.

Polunin, N. 1940. Botany of the Canadian Eastern Arctic. Part I. Pteridophyta and Spermatophyta. Nat. Mus. Canada Bull., 92, 408 p. 1948. Botany of the Canadian Eastern Arctic. Part III. Vegetation and ecology. Ibid., 104, $304 \mathrm{p}$.

Porsild, A. E. 1957. Illustrated flora of the Canadian Arctic Archipelago. Nat. Mus., Canada Bull., 146, 209 p.

Romer, A. S. 1951. Bison crassicornis in the late Pleistocene of New England. J. Mammal., 32:230-231.

Rosendahl, G. O. 1948. A contribution to the knowledge of the Pleistocene flora of Minnesota. Ecology, $29: 284-315$.

Rubin, M. and G. Alexander 1960. U. S. Geological Survey Radiocarbon Dates V. Am. J. Sci., Radiocarbon Supplement, $2: 129-185$.

Scinofield, W. B. AND. H. Robinson 1960. Late-glacial and postglacial plant macrofossils from Gillis Lake, Richmond County, Nova Scotia. $A m$. J. Sci., 258:518-523.

Wilson, L. R. 1932. The Two Creeks forest bed, Manitowoc County, Wisconsin. Trans. Wisconsin Acad. Sci.; Arts and Letters, 27:31-46. 1936. Further fossil studies of the Two Creeks forest bed, Manitowoc County, Wisconsin. Bull. Torrey Bot. Club, 63:317-325. 